\title{
Assessing the Challenges of Irrigation Development in Ethiopia: A Review
}

\author{
${ }^{1}$ Mesfin Meja \\ ${ }^{1}$ Lecturer, \\ Department of Hydraulic and Water Resources \\ Engineering, Wolaita Sodo University, Ethiopia.
}

\author{
${ }^{2}$ Matusala Bassa \\ ${ }^{2}$ Lecturer, \\ Department of Civil Engineering, \\ Wolaita Sodo University, Ethiopia.
}

\author{
${ }^{3}$ Teketel Mirkeno \\ ${ }^{3}$ Lecturer, \\ Department of Hydraulic and Water Resources Engineering, \\ Wolaita Sodo University, Ethiopia.
}

\begin{abstract}
This study reviewed to assess the challenges of irrigation development in Ethiopia based on use and development of irrigation water and its contributions to the national economy, opportunities, and future development perspectives. Although, Ethiopia is considered as a water tower of Africa, only 5\% irrigation potential is developed yet. It is believed that irrigation can increase security of crop production and income earning. Concurrently, in many parts of the country; it uplifted the food security of many smallholder farmers. However, evidence has shown that there are several challenges on the performance of irrigation schemes and most are not performing at the best of their capacity. The key challenges impeding the success of irrigation development are; poor scheme management, imperfect market, financial shortage, insufficient technical skill, lack of awareness about the use of irrigation, environmental and, social impact and institutional challenges. Local resources and adequate catchment management; soil and water conservation using physical and biological measures is essential. Poor irrigation management is highly related to lack of sufficient skills. Thus, expansion of training for farmers and water user associations by governmental and nongovernmental organizations will have a significant impact on irrigation development. There is a strong need to improve access to market information to irrigators in other to improve the system in general and an effective extension system should be in place to guide farmers to manage traditional irrigation efficiently This paper argues that there is a need of attention by irrigation administrators, policy makers and development practitioners to tackle these challenges in order to develop irrigation potential and to solve food insecurity in Ethiopia.
\end{abstract}

Keywords: Ethiopia, challenges, irrigation development, impacts

\section{INTRODUCTION}

Ethiopia is a landlocked country, with a land area of 1.13 million $\mathrm{km}^{2}$, found in Eastern Africa [1]. Geographically, it is located in between the latitudes $5^{\circ} \mathrm{N}$ and $15^{\circ} \mathrm{N}$, and longitudes $35^{\circ} \mathrm{E}$ and $45^{\circ} \mathrm{E}$ [1]. The country is bordered by six countries, Eritrea in the North, Djibouti and Somalia in the East, Kenya and Somalia in the South, and Sudan and South Sudan in the West. Ethiopia's population is estimated at 80 million and is the second most populous country in Africa next to Nigeria [1]. Most of the population in Ethiopia lives in highland areas, with $85 \%$ being rural and dependent on agriculture with a low level of productivity [1].

Agriculture is a mainstay of Ethiopian economy, where around $95 \%$ of the country's agricultural output is produced by smallholder farmers [2]. The country is endowed with ample water resources with 12 river basins with an annual runoff volume of 122 billion $\mathrm{m}^{3}$ of water and an estimated 2.6-2.65 billion $\mathrm{m}^{3}$ of groundwater potential [1]. Due to this Ethiopia is considered to be the water tower of Africa [3]. The cultivated agricultural land of Ethiopia currently under cultivation is about 12 million ha [4]. Moreover, even if the potential and actual irrigated area is not precisely investigated [5], estimates of irrigable land in Ethiopia vary between 1.5 and 4.3 million hectares (Mha), averaged about 3.5 Mha [6]. However, it is surprising that the total land under irrigation now is estimated to be in the range between $160,000-200,000$ ha which is less than $5 \%$ of the country's irrigable land [1]. However, [7] reported about $10-12 \%$ of the total irrigable potentials are currently under production using traditional and modern irrigation schemes. Moreover, differences in irrigation potentials and actually irrigated lands, for example 3.7 Million ha and 197,000 ha according to [1] and 3.5 Million ha and 626,116 ha as reported by respectively, are indicated differences in the same class. Hence, there is no consistent and reliable inventory and well-studied and documented with regards to water and irrigations related potentials in the Ethiopian context. This shows that there is little study details in the area. This knowledge is important in such a way that the people and government who are living today become aware of what the people and governments in the past had done in the sector.

Irrigation use in Ethiopia dates back several centuries, and continues to be an integral part of Ethiopian agriculture. In Ethiopia, modern irrigation began in the 1950s through private and government-owned schemes in the middle Awash Valley where big sugar, fruit and cotton state farms are found [8]. In Ethiopia, irrigation development is a priority for agricultural transformation, but poor practices of irrigation management discourage efforts to improve livelihoods, and expose people and the environment to 
risks [8]. Irrigation projects have been failing mainly because of insufficient participation by beneficiaries and insecurity of land tenure. Socioeconomic, cultural, religious and gender-related issues pose a problem to full and equal participation by beneficiaries [9]. Moreover, the poor performance of irrigation in the country, systematic and holistic evaluation of irrigation management in general and of small-scale irrigation in particular is lacking [10]. The main purpose of irrigation development in the $1960 \mathrm{~s}$ was to provide industrial crops for agro-industries in the country. The agro-industries were established by foreign investors and had the objective of increasing export earnings.

In most parts of Ethiopia, production from rain-fed agriculture has been highly fluctuating, corresponding to the amount and distribution of rainfall [11]. When there is too little rainfall with uneven distribution, crop failure is unavoidable. In spite of all this, agricultural growth still contributes to the improvement of food security conditions and household empowerment in the country. However, as it now stands, droughts occur far too often and food security in all its extent could not be sustained. Irrigation would have to be introduced in a significant way for a sustainable attainment of food security and rural transformation at the national level [12]. The objective of these studies is therefore important for understanding what are the challenges and constraint on irrigation developments in Ethiopia.

\section{METHODOLOGY}

The studies were based on intensive reading of published and unpublished materials like books, articles and other scholarly materials.

\section{USE OF IRRIGATION WATER IN ETHIOPIA}

Water is mankind's most vital and versatile natural resource [13] and has always played an essential role in Ethiopian society as it is an input to almost all production systems [14]. Water is also considered as an essential resource for irrigation. Irrigation can be defined as an artificial application of water to soil for the purpose of supplying the moisture essential in the plant root-zone to prevent stress that may cause reduced yield and/or poor quality of harvest of crops [15]. This is an intentional action made by human to apply water for growing crops, especially during dry seasons where there is a shortage of rainfall. Water applications to crop fields are of various types. The most commonly used and most ancient type is surface irrigation methods [16] through the usage of gravity forces. This was used especially across river sides and it doesn't depend on mechanized equipment. Nowadays, modernized irrigation systems are mostly used which works based on the pressurized energy system [17]. The sprinkler and drip irrigation systems are of this type of water application systems. Irrigation in Ethiopia is considered as a basic strategy to alleviate poverty and hence food security. It is useful to transform the rain-fed agricultural system which depends on rainfall into the combined rain-fed and irrigation agricultural system. This is believed to be the most prominent way of sustainable development in the country. However, the development of irrigation practices in Ethiopia has to be investigated so as to seriously know the history of irrigation emergence and its subsequent developments.

\section{WATER DEVELOPMENT EXPERIENCE IN ETHIOPIA}

Concerning the potential and practice of irrigation in Ethiopia, there are different views by different writers. Ethiopia is a rich country in having considerable water resource potential and considered as a water tower of Africa [18]. However, the level of development of the sector is very low despite, the country's considerable endeavors to promote development of the sector. As a means of dealing the problem Ethiopian Government has formulated policies, strategies and programs for water resources development. Even though there are a number of components of water resource development, irrigation is presently one of the priorities of the Ethiopian Government as can be seen from the resources budgeted for irrigation development. The overall national potential for small, medium and large-scale irrigation is between 1.8 and 3.4 million hectares. To date, there are about 190,000 hectares brought under irrigation in the country and there are plans to double this area [12]. The government's strategy emphasizes the importance of enhancing small farm productivity and irrigation as key factors of success in increasing the overall agricultural productivity and crop diversification. Further proof of the importance attached to irrigation is the USD75 million for small-scale irrigation program component in the Ethiopian Social Rehabilitation and Development Project (ESRDP) approved in March 1996. In this frame, small-scale irrigation (SSI) is expected to provide facilities for some 87,850 households on altogether 18,700 hectares of land. In Ethiopia, Modern irrigation schemes construction began in the second half of the 1950s [19]. They were at large scale and managed by parastatals. As to irrigation potential of the country, there are different estimates despite the availability of a relatively 32 more recent and accepted figure, 2.7 million hectares [19], Water and development. The irrigation development trend in Ethiopia seems very low even when compared with other African countries [19]. Irrigated land accounts less than $2 \%$ of cropped land. The objective of irrigation development is changing from time to time. At the beginning irrigation water was mainly used for developing cash crops like sugar cane, cotton, sesame fruit and vegetables at large scale; latter food security became an area of focus (target) for irrigation schemes development; similarly, since the mid-1980s the Ethiopian Government have been giving due attention about the desirability of small- scale irrigation development schemes [19]; even though their impact so far is limited due to a number of factors [20].

\section{WAYS OF IRRIGATION DEVELOPMENT IN ETHIOPIA}

[21] noted that irrigation development is a key for sustainable and reliable agricultural development which leads to overall development in Ethiopia. Irrigated agriculture is being practiced under smallholders, medium and large-scale farming. Many authors such as [4] were 
used government-based irrigation schemes classification systems for their description during their studies. According to Ministry of Water Resources of Ethiopia [21], irrigation development in Ethiopia is classified based on the size of the command area, in three types:

1. Small-scale irrigation systems $(<200$, ha)

2. Medium irrigation systems (200-3,000 ha)

3. Large-scale irrigation systems $(>3,000 \mathrm{ha})$

This classification system is the most common in Ethiopia. Accordingly, $46 \%$ of proposed irrigation developments are in the small-scale irrigation category [21]. Table 1 summarizes the typologies of irrigation schemes in Ethiopia.

Table 1 Summary of typologies of irrigation schemes in Ethiopia.

\begin{tabular}{|l|l|l|l|}
\hline Typology & $\begin{array}{l}\text { Size of } \\
\text { scheme(ha) }\end{array}$ & Infrastructure & $\begin{array}{l}\text { Water } \\
\text { management } \\
\text { scheme(ha) }\end{array}$ \\
\hline $\begin{array}{l}\text { Small- } \\
\text { scale }\end{array}$ & $<200$ & $\begin{array}{l}\text { Fixed or improved } \\
\text { water control and } \\
\text { diversion structures } \\
\text { made }\end{array}$ & $\begin{array}{l}\text { Water users' } \\
\text { association or } \\
\text { irrigation } \\
\text { cooperatives. } \\
\text { Local water } \\
\text { users' } \\
\text { association }\end{array}$ \\
\hline $\begin{array}{l}\text { Medium } \\
\text { scale }\end{array}$ & $200-3000$ & $\begin{array}{l}\text { Fixed or } \\
\text { improved water } \\
\text { control and } \\
\text { diversion } \\
\text { structures. }\end{array}$ & $\begin{array}{l}\text { Water users' } \\
\text { association/ } \\
\text { irrigation. } \\
\text { cooperatives } \\
\text { or state }\end{array}$ \\
\hline $\begin{array}{l}\text { Large } \\
\text { scale }\end{array}$ & $>3000$ & $\begin{array}{l}\text { Fixed or } \\
\text { improved water } \\
\text { control and } \\
\text { diversion } \\
\text { structures. }\end{array}$ & $\begin{array}{l}\text { Mostly state } \\
\text { enterprises }\end{array}$ \\
\hline
\end{tabular}

Source: [6].

\section{FACTOR'S AFFECTING IRRIGATION DEVELOPMENT ACTIVITIES IN ETHIOPIA}

The successes of irrigation development generally depend on the cooperation of larger range of government institutions and individuals, such as, for instance, the departments of irrigation, extension and rural works, banks and planning bodies. Unsurprisingly, development issues are interrelated and water resource developments by nature have interrelation with many factors. Consequently, irrigation developments are also determined by many factors for their success. As stated by [22], the performance of irrigation schemes depends on: cropping pattern, market accessibility, maintenance and spare parts, social and political, and land tenure policies. Some major factors that negatively affect irrigation development in Ethiopia are:

\section{ENVIRONMENTAL IMPACT}

Salinity and Sodicity/alkalinity are the major problems that resulted in the valley due to irrigation practices in the enterprise. In some places high salinity and sodicity/alkalinity levels coupled with poor drainage of the soils are at present resulting in quite a large area of productive lands being abandoned from cultivation. Over 2,000 ha of the Melka Sedi-Amibara State Farm that was cultivated for bananas for about 16 years (1971-1986), and other areas that were cultivated for cotton recently (19821992), have gone out of cultivation due to these problems. The other environmental impact, that is usually associated with the establishment of the enterprise, is the introduction and invasion of a thorny shrub by the name of Prosopis julifora in the Middle Awash Valley. The plant/weed covers most of the area near the enterprise, which was once barren land during dry seasons and possibly used for grazing purposes during wet seasons. Even if it has some benefits in reducing wind erosion and increasing the organic matter content of the soil, it created problems both to the enterprise and the surrounding inhabitants as it affects the canal network of the farms and cannot be used as animal feed. Water borne diseases also an environmental impact resulting from irrigation projects are examples of diseconomies/ external costs imposed by the project to the society [23]. In support of this, [24] indicates that water related diseases and treats to flood plain ecosystem are other high environmental costs. Water withdrawn for irrigation impacts the naturally occurring environmental services provided by free-flowing rivers as do changes in flow regimes caused by associated dams. Habitat and resident flora and fauna are destroyed, and the flooding of biomass may result in net releases of carbon dioxide (CO2) and methane (CH4). This may have impacts on global climate and localized air pollution problems.

\section{SOCIAL AND CLIMATE-RELATED IMPACTS}

Although the actual infrastructure for the proposed schemes has not been confirmed at this stage, it is likely that the schemes may have irrigation infrastructure (diversion weirs, small dams with walls/embankments, shallow wells, boreholes, conveyance canals, secondary/tertiary/field canals headwork's, pipes, water storage facilities, pumps, pump houses and drainage lines); access infrastructure (access roads, bridges and footpaths), ancillary facilities (workshops, sheds, offices and fuel storage). Interventions for watershed management essentially include water conservation and soil conservation, such as water harvesting using contour bunds / benches, water spreading bunds, micro-catchments, water storage facilities such as small dams and sand dams, biological measures, and production techniques such as conservation agriculture. Change in interest rate, such huge investments are sensitive to cost of capital fluctuations. Participation in community activities and membership of voluntary organisations and clubs may decline in the short term, as newcomers adjust to their new circumstances, but strengthen in the longer term. Value conflicts between some urban residents and farming communities over the environmental impacts of intensive farming systems.

Increases in standing water associated with irrigation, especially when systems are poorly managed, can serve as a breeding-ground for disease vectors including Anopheles mosquitos, contributing to increases in malaria and other disease. Similarly, dams constructed for irrigation slow water flow and may increase the prevalence of malaria or sleeping sickness. Irrigation with un- or minimally treated wastewater can increase exposure of both producers and 
consumers to pathogens resulting in schistosomiasis, diarrhea or other ailments [25]. Irrigation with chemically contaminated water, either natural as in arsenic [26]or human induced [23] has clear health implications. The availability of irrigation can encourage use of other agricultural inputs including fertilizer and pesticides, increasing exposure of both farmers and consumers.

\section{ECONOMIC AND POLITICAL IMPACTS}

Irrigation influenced changes in agricultural productivity have been shown to impact overall growth through multiplier effects and can free human and financial capital for industry and services [27], stabilize rural populations [28] and impact foreign exchange earnings and budgets via export taxes.

Irrigation may also influence overall governance structures. While governance change may typically be a by-product of irrigation, it can also be an explicit objective. Similarly, electricity reform to support overall economic growth is complicated by the political economy of power subsidies and groundwater.

\section{OPPORTUNITIES AND CHALLENGES}

Ethiopia enjoys a fast-expanding irrigation subsector as previously presented. This is due to the enormous untapped irrigation potential, the need to provide food, industrial raw materials, and labor to a large and growing population, and the improving business climate in the country. Domestic and foreign investors are provided with incentives to establish an export-oriented horticultural company. Incentives include (among others) the duty-free importation of production equipment and an income tax holiday. Ethiopia's recent economic and development performance is staggering; economic growth averaged 10.6 percent per year from 2007 to 2012. Ethiopia still relies heavily on food aid, receiving 25 percent of global food aid for Sub Saharan Africa. There is an enormous need to invest in irrigated agriculture to ensure food security for a population of over 92 million. Government donor supported projects are also playing an increasingly important role in the commercialization of agriculture. But despite its impressive growth, Ethiopia's agricultural sector is underperforming. The sector's commercialization and modernization are severely constrained by a lack of financing. This is exacerbated by the following [29]:

- Unclear land access procedures

- Lack of access to inputs and financing

- Inadequate farming skills

- Lack of resources for maintenance of irrigation structures

- Resistance to the adoption of new technologies/crops by traditional cereal farmers, combined with Ethiopian farmers' extreme risk aversion

- Poor agricultural extension and irrigation water management-related service delivery, particularly for small-scale farmers

- Frequent drought leading to rapid depletion of some water resources
- Lack of access to technical and market information (leading to high transaction costs)

- Insufficient physical infrastructure, particularly power supply to rural areas

- Depletion of water resource and dependent life systems: (i.e., ecological problem of surface and ground water development for marginal water quality areas).

- Conflicts (e.g., trans-boundary, between upper and downstream users, between management and users, implementers and donors etc.) [30].

- Flood and erosion: appropriate surface drainages and effective operation are, therefore, critical for productive and sustainable irrigation in particular since canals are long, and it is difficult to adjust head diversions. Since some are vulnerable to excess water, irrigation-system is responsive not only to the problems of little rainfall but also to problems of too much rain (WB 129:25).

- Drainage challenges: renewability issues, seepages, canal lining, theft and vandalism of control structures [31].

- Market prices for crops: irrigation projects may exhibit negative net present value (NPV) upon implementation due to change in market prices of goods from what is expected during the time of feasibility studies.

- Maintenance challenges and quality of design: the quality of design and maintenance system can also determine their sustainability.

- Pest infestation and input shortages: are also some of the areas of concern due to their significant contribution as a threat.

\section{MAIN GAPS TO PROMOTE, IRRIGATION DEVELOPMENT IN ETHIOPIA}

The following lists are key constraints, knowledge gaps and broad research needs in effectively implementing the technologies of irrigation and rain water harvesting in Ethiopia [32]:

\section{Main Constraints}

- Lack of or inadequacy of baseline studies, data and information on potentials of different areas for the development of water resources

- Poor technology choice

- Low yields

- Property rights

- Too small landholdings

- Conflicts in water use and use rights

- Marketing and market access

- Dependency syndrome

- Institutional arrangements and instability

- Lack of training to handle technologies; lack of extension services

- Lack of start-up capital or access to credit to initiate venture

- $\quad$ Poor linkage between research and extension in the area of irrigation water management 


\section{Main knowledge gaps}

- Faulty design

- Lack of knowledge on use of modern irrigation technology

- Poor water management

- Poor land management

- Poor input utilization

- Poor management capacity

- Lack of information and database

- Lack of post-harvest technology and management Future Opportunities

- High water potential

- High commitment of the Ethiopia government, donors and NGOs to support irrigation management and development activity

- Opportunity for implementing multiple use water systems (MUS), with regions coordinating subactivities. Effective utilization of scheme infrastructure through diversification of uses to meet various needs for water such as domestic, irrigation, livestock and hygiene is the most important.

- Opportunities for improving knowledge of policy makers, planners, designers. Contractors and development agencies through education, training, dialogues and participation

- Opportunities for more gender-equitable investments, targeting poor women, through for example MUS and micro irrigation

\section{THE ENVIRONMENTAL POLICY OF ETHIOPIA}

The Environmental Policy of Ethiopia, approved in 1997, is aimed at guiding sustainable social and economic development of the country through the conservation and sustainable utilization of the natural, man-made and cultural resources and the environment at large. The policy lists specific objectives encompassing wide range of environmental issues to be addressed through the adoption of the policy. It also provides overarching environmental guiding principles to be adopted to harmonize the environmental elements in sectoral, cross-sectoral and other policies. The policy clearly outlined the sectoral environmental policies, relevant to environmental management among others are: (i) Soil Husbandry and Sustainable Agriculture; (ii) Forests, Woodlands and Trees; (iii) Genetic, Species and Ecosystem Biodiversity; (iv) Water Resources; (v) Energy Resources; (vi) Human Settlement, Urban Environment and Environmental Health; and (vii) ESIA.

\section{WATER RESOURCE MANAGEMENT POLICY OF ETHIOPIA}

Ethiopian Water Resources Management Policy was set out in Proclamation No. 197/2000 (the "WRM Proclamation"). The policy is intended to promote comprehensive and integrated water resources management and optimal utilization of available water resources for sustainable socio-economic development. Inter alia, the policy calls for conservation and protection of water resources as an integral feature of the water resources planning and development process, and therefore mandatory EIAs of all water resource development projects. The policy entrusts the Ministry of Water Resources (now Ministry of Water, Irrigation and Energy (MOWIE)) with broad powers to plan, manage, use, administer and protect water resources, including the promotion and implementation of irrigation projects. The sub-sectoral policies include Irrigation, Hydropower, and Water Supply and Sanitation, each with an associated Strategy. The Policy was elaborated in the Ethiopian Water Sector Strategy (2001), also known as the National Water Strategy. The purpose of the Strategy is to translate the Policy into action, with the following specific objectives:

- Improving the living standard and general socioeconomic well-being of the Ethiopian people.

- Realizing food self-sufficiency and food security in the country.

- Extending water supply and sanitation coverage to large segments of the society, thus achieving improved environmental health conditions.

- Generating additional hydro-power.

- Enhancing the contribution of water resources in attaining national development priorities.

\section{REVIEW NEEDS}

These studies need specific to this paper can be grouped into the following broad categories:

- Policy research - strategic policy research to enhance the improvement of national level policies and processes, and to enhance the realization of broader poverty and food security impacts of smallholder irrigation interventions at national, regional and local (community and household) levels.

- Socio-economic and market research - research on marketing and market information so that farmers can produce targeted crops using irrigation was a general issue in all regions; market surveys and analysis so that farmers can produce according to market requirements; input supply arrangements during irrigation period; research on how to successfully upgrade traditional schemes into modern ones, including organizational issues related to WUA formation; benefit-cost analysis for alternative irrigation technologies taking into account affordability, accessibility, maintenance and sustainability.

- Institutional research - research to establish clear and effective policies to minimize conflicts between upstream and downstream water users, problems of institutional arrangements in regional structures was acknowledged as relevant in all regions except Oromia; research on property rights regarding access to land and water was emphasized, particularly clear definition of rights to water to minimize conflicts between traditional irrigator and those on modern small scale scales.

\section{Conclusion}

\section{CONCLUSION AND RECOMMENDATION}

Irrigation development in Ethiopia, as elsewhere in subSaharan Africa, Asia and beyond, is hindered by serious problems related to water management. As a result, unfair 
water distribution within the schemes and inefficient water use are common in Ethiopia. Storage structures (e.g. dams, reservoirs etc.) and primary and secondary channels are not properly maintained due to a lack of resources. These phenomena are the result of the absence or weakness of irrigation development management.

This study reviewed to assess the challenges of irrigation development in Ethiopia based on use and development of irrigation water and its contributions to the national economy, opportunities, and future development perspectives. The evidence that the main challenges of irrigation use has weak management capacity, lack of awareness, giving training for the farmers how to use and management of irrigation although it is a necessary condition for efficient and lasting irrigation management. The water use teams (WUT) are not properly organized to run irrigation management. Users have problematic social relation. Enabling legal systems of land water rights institutions are non-existent at the operational level. Efforts of stakeholders were not harnessed in irrigation administration. These problems in turn have drastically affected management and utilization of the developed resources. The major problem of irrigator households is increment of input costs such as pesticides, insecticides and fertilizes. The use of inputs influences household income from crop production. The input cost increments and unavailability of the inputs when required by the farmers are also the main problems. Poor market access is the major factor that limits trade interaction between the livelihood and external markets. The poor roads and the remote location severely restrict the flow of goods in and out. So the farmers suffered from different challenges including: transportation, distance from the market, low bargaining power, and low prices of agricultural inputs.

Therefore, policies for future investment in irrigation development and for rehabilitation of the irrigation systems considered by this study should give due consideration to averting these problems.

\section{RECOMMENDATION}

The general recommendation from this study is to advise policy makers, development agencies and irrigation administrators tackle these key challenges, so that irrigation development performance can be improved. An innovative approach to irrigation management is necessary. This innovative approach should be farmer centered. In this respect attention needs to be paid on empowering farmers through trainings, provision of special irrigation focused credit services and legalizing water use systems. Salinity, sediment concentration, and land degradation as a result of poor management are common features of many schemes. In order to mitigate such factors mobilization of local resources and adequate catchment management; soil and water conservation using physical and biological measures is essential. Poor irrigation management is highly related to lack of sufficient skills. Thus, expansion of training for farmers and water user associations by governmental and nongovernmental organizations will have a significant impact on irrigation development. There is a strong need to improve access to market information to irrigators in other to improve the system in general and an effective extension system should be in place to guide farmers to manage traditional irrigation efficiently.

\section{BIBLIOGRAPHY}

[1] Gebremedhin Gebremeskel Haile and Asfaw Kebede Kasa "Irrigation in Ethiopia: A review," Academia Journal of Agricultural Research, vol. 3, no. 10, pp. 264-269, 2015.

[2] Dagninet Asrat and Adugnaw Anteneh, "The determinants of irrigation participation and its impact on the pastoralist and agropastoralists income in Ethiopia: A review study," Cogent Food \& Agriculture, vol. 5, no. 2, 2019.

[3] Godswill Makombe and Dawit Kelemework Mekonnen, "A comparative analysis of rainfed and irrigated agricultural production in Ethiopia," Irrigation and Drainage Systems, vol. 21, no. 2, p. 35 44, 2007.

[4] Godswill Makombe, Regassa Namara, Fitsum Hagos, Seleshi Bekele , Awulachew, Ayana and Deborah Bossio, "A Comparative Analysis of the Technical Efficiency of Rain-fed and Smallholder Irrigation in Ethiopia," International Water Management Institute, vol. 143, no. 4, 2011

[5] Mehretie Belay and Woldeamlak Bewket, "Farmers' livelihood assets and adoption of sustainable land management practices in north-western highlands of Ethiopia," International Journal of Environmental Studies, vol. 70, no. 2, pp. 284-301, 2013.

[6] G. G. Haile, "Irrigation in Ethiopia, a Review," Journal of Environment and Earth Science, vol. 5, no. 15, 2015.

[7] Yilma, Z., G.B., Emannuelle and S., Ameha., "A Review of the Ethiopian Dairy Sector," Food and Agriculture Organization of the United Nations, Sub Regional Office for Eastern Africa, p. 81, 2011.

[8] Dereje Mengistie and Desale Kidane, "Assessment of the Impact of Small-Scale Irrigation on Household Livelihood Improvement at Gubalafto District, North Wollo, Ethiopia," agriculture, vol. 6, no. 27, 2016.

[9] Desale Kidane, Amanuel Mekonnen and Demel Teketay, "Contributions of Tendaho Irrigation Project to the Improvement of Livelihoods of Agropastoralists in the Lower Awash Basin, Northeastern Ethiopia," Ethiopian e-journal For Research and Innovation Foresight, vol. 6, no. 2, pp. 1-19, 2014.

[10] Melvyn Kay FAO/IPTRID Consultant, "SMALLHOLDER IRRIGATION TECHNOLOGY: PROSPECTS FOR SUBSAHARAN AFRICA," IPTRID Secretariat Food and Agriculture Organization of the United Nations, Rome, Italy, 2001.

[11] Kidane, D, Temesgen, M and Abdelkadir, A, "Effect of winged subsoiler and traditional tillage integrated with Fanya Juu on selected soil physico-chemical and soil water properties in the north western highlands of Ethiopia.," East Afr. J. Sci., vol. 6, pp. 21-32, 2012.

[12] D. Kidane, " Conservation tillage implementation under rain-fec agriculture: Implication for soil fertility, green water management, soil loss and grain yield in the Ethiopian Highlands.," Int. J. Agric. Sci., vol. 4, p. 268-280, 2014.

[13] Nata T, Asmelash B and Bheemalingeswara K, " Initiatives, Opportunities and Challenges in Shallow Groundwater Utilization: a Case Study from Debrekidane Watershed, Hawzien Woreda, Tigray Region, Northern Ethiopia.," Agricultural Engineering International: the CIGR Ejournal., vol. 6, no. 22, 2008

[14] MoWR, " Ethiopia: Managing Water Resources to Maximize Sustainable Growth,," A World Bank Water Resources Assistance, Ethiopia, 2006.

[15] R. Reddy, Irrigation Engineering, New Delhi: Gene-Tech, 2010.

[16] Andreas P. SAVVA and Karen FRENKEN, Surface Irrigation Systems Planning, Design, Operation and Maintenance, Harare: Water Resources Development and Management Officers FAO SubRegional Office for East and Southern Africa, 2002.

[17] FAO, "Planning, Development Monitoring and Evaluation of Irrigated Agriculture with Farmer Participation," Irrigation Manua, vol. 3 , no. 8,2001 . 
[18] Dagmawi Mulugeta Degefu, Weijun He and Jian Hua Zhao, "Hydropower for sustainable water and energy development in Ethiopia," Sustain. Water Resour. Manag., vol. 1, p. 305-314, 2015.

[19] G. Birhane, "Present and future water resources development in Ethiopia related to research and capacity building," Planning and Projects Department, Ministry of Water Resources, Addis Ababa, Ethiopia, 1999.

[20] F. Adam, "Small-scale Irrigation and Household Food Security: A Case Study from Central Ethiopia," Forum for Social Studies.Addis Ababa, vol. 4, no. 2, 2001.

[21] Makombe G, Namara R, Hagos F, Awulachew SB, Ayana M and Bossio D, "A comparative analysis of the technical efficiency of rainfed and smallholder irrigation in Ethiopia," International Water Management Institute, p. 37, 2011.

[22] B. N, " Policies and Institutions to Enhance the Impact of Irrigation Development in Mixed Crop-Livestock," MoWR/EARO/IWMI/ILRI Workshop, Addis ababa,Ethiopia, 1995.

[23] Shah, Tushaar, Barbara van Koppen, Douglas J, Merrey, Marna de Lange and Madar Samad, " Institutional alternatives in African smallholder irrigation," Lessons from international experience with irrigation management transfer. Research Report 60. , Colombo, Sri Lanka: IWMI., 2002.

[24] Michael M. Girma and Seleshi B. Awulachew, "Irrigation Practices in Ethiopia: Characteristics of Selected Irrigation Schemes," International Water Management Institute, 2007.

[25] P. Amoah, Drechsel, P, Abaidoo, R. C and Abraham, E. M, "Improving food hygiene in Africa where vegetables are irrigated with polluted water," 2009.

[26] Senanayake, N and Mukherji, A, "Irrigating with arsenic contaminated groundwater in West Bengal and Bangladesh: A review of interventions for mitigating adverse health and crop outcomes.," Agricultural water management, vol. 135, pp. 90-99, 2014.

[27] J. . Anderson, Dillon, J. L, Hazell, P. B. R, Cowie, A. J and Wan, G. $\mathrm{H}$, "Articles and Notes Changing Variability in Cereal Production in Australia. Review of Marketing and Agricultural Economics," vol. 56, no. 3, 1988.

[28] B. Schraven, "Irrigate or migrate? Local livelihood adaptation in Northern Ghana in response to ecological changes and economic challenges.," Unpublished PhD thesis, 2010.

[29] N. T. Henkaro, "The Role of Irrigation Development in Enhancing Household Food Security: A Case ofTI1ree Small-Scale Irrigation Scl1emes ill SOllt1leru Natiolls, Natiollalities ami Peoples' Regioll.," ADDIS ABABA UNIVERSITY RESEARCH AND GRADUATE PROGRAMS OFFICE REGIONAL AND LOCAL DEVELOPMENT STUDIES, 2002.

[30] D. Rhameto, "Water Resources Development in Ethiopia: Issues of Sustain Abilities and Participation," Forum for Social Studies, 1999.

[31] D. Campbell, "Design and Operation of Smallholder Irrigation south Asia," in Irrigation and Drainage series Washington D.C., 1995.

[32] I. W. M. Institute, "Assessment of Experience and Opportunities in Small Scale Irrigation, Rain Water Harvesting in Ethiopia," Unpublished, 2004. 